\title{
Den journalistiske automatskrift - når sproglige normer bliver til sproglige dogmer
}

\section{AF LEIF BECKER JENSEN}

Det journalistiske sprog er-i lighed med det akademiske - præget af en normativ og ensartet skrivetradition, som journalister tilegner sig gennem mesterlære og imitation. Sprognormerne internaliseres som "mavefornemmelser", og det betyder, at sproglige og stilistiske valg foretages pr. intuition på traditionens egne præmisser. Derfor fremstår sprognormerne ofte som dogmatiske sandheder, der ikke problematiseres, og det kan udelukke andre og måske mere hensigtsmæssige valg ud fra et funktionalistisk sprogsyn. Disse manglende valgmuligheder diskuteres i denne artikel ud fra journalistiske lærebøger med verbets passivform som illustrerende eksempel.

"Kvinde fundet død i lejlighed", skriver journalistpraktikanten i rubrikken, men bliver irettesat af redaktionssekretæren. Praktikanten har brugt den passive form af verbet, og det gør man ikke. Så rubrikken blive skrevet om med aktivt handleverbum og tilhørende subjekt: "Nabo fandt kvinde død i lejlighed”. Sådan redaktionssekretæren er tilfreds, og praktikanten gør det næppe igen.

Episoden er et lille eksempel på journalistisk automatskrift i funktion, dvs. journalisten vælger en bestemt sproglig og stilistisk udtryksform pr. automatik, og samtidig er episoden et eksempel på en socialisering af næste journalistgeneration ind i den samme sprogkultur.

Begrebet 'automatskrift' dækker i denne artikel over det fænomen, at professionelle skribenter vælger en bestemt sproglig og stilistisk udtryksform uden nogen særlig refleksion, men fordi 
den sidder på rygmarven. Ofte kan journalisten endda have svært ved at give en eksplicit begrundelse, hvis han bliver afkrævet en, fordi sproglige valg og fravalg sker inden for en bestemt tradition forankret i en institution med en ensartet og normativ sprogkultur.

Allan Bell (1991), der har 'et ben i hver lejr' som både lingvist og journalist, har undersøgt nyhedsmediernes sprog, især i England og New Zealand, ud fra en sociolingvistisk tilgang og har med mange empiriske eksempler argumenteret for, hvordan de redaktionelle diskurser og forretningsgange former det journalistiske sprog og de journalistiske tekster.

Tilsvarende har Coleen Cotter (2010), der også både er lingvist og tidligere har arbejdet som nyhedsjournalist og redaktør, undersøgt, hvordan normer og redaktionel praksis former det journalistiske (nyheds)sprog med udgangspunkt i såvel amerikansk som engelsk presse.

I dansk journalistik er vi som bekendt stærkt influeret af den angelsaksiske tradition, og derfor kan mange af deres pointer uden større vanskeligheder overføres til Danmark.

\section{Den normative sprogkultur}

Cotter er særlig relevant i denne sammenhæng, fordi hun bruger det centrale begreb 'the prescriptive imperative' for den normative sprogkultur, man følger som professionel journalist (Cotter, 2010:212):

"Language ideologies are (...) embodied in journalists themselves who reiterate culturally situated norms through processes of news production; they actively follow the prescriptive imperative that helps to create their professional identity."

Konsekvensen af dette imperativ er en standardisering af sprogkoden (ibid.:188):

"A standard language means that one form or variety of usage is preferred, privileged, and expected to be used in particular social 
contexts and discourse situations, and is considered the norm to aspire to."

Der er derfor også en indbygget inerti og konservatisme i sprogkoden (ibid.:187):

"Journalists' language attitudes are conservative, prescriptive, and mainstream; their role in societal situated language standardization is complex but robust (...) Standardization in the journalistic realm is also discursive. Well-formed news discourse is structured by a fairly strict set of rules that govern how information is selected and presented, leading to an identifiable 'news style'."

Dette 'prescriptive imperative' kan ifølge Cotter beskrives og forklares ud fra fire parametre, nemlig:

1) Et lingvistisk, som favoriserer bl.a. bestemte former for syntaks og stilistik, fx brugen af aktiv frem for passiv, 2) Et sociolingvistisk, som udpeger den sprognorm, der giver prestige i gruppen, 3) Den sociale kontekst, fx magtfulde institutioner som skoler og brancher, og 4) Det operationelle, hvor normerne omsættes til konkrete handlingsanvisninger, fx i form af manualer og stylebooks. Mange journalistiske lærebøger, især inden for 'how-todo-it-genren', vil jeg henregne til denne sidste kategori.

Det er også vigtigt at understrege uddannelsernes praksisdimension med færdighedsindlæring og praktikkens videreførelse af den gamle mesterlære. Det indebærer en socialisering ind i faget, hvor normerne medindlæres, så viden og færdigheder placeres i forhold til professionens selvforståelse og værdier (ibid.:49):

"Nowadays, reporters learn their craft in college or university in undergraduate or master's-level journalism programs, from textbooks, through newsroom internships, and on-the-job, the last functioning as a daily renewal of skills, values, and priorities throughout the duration of a career (...) Socialization into the profession is a complex process, involving internalizing a set of assumptions of practice and professional identity." 
Det er derfor også typisk, at journalister kan have svært ved at begrunde deres valg, men bygger på "mavefornemmelser", dvs. en intuitiv fornemmelse af det gode henholdsvis dårlige sprog. Det er typisk for professionelle udøvere af praktiske fag og svarer til, hvad Schön (1981) har kaldt 'reflection-in-action' - i modsætning til at reflektere over praksis. Det modsvarer nogenlunde forskellen mellem at vide, hvordan man udfører noget, og begrunde, hvorfor man udfører det på netop denne måde. I parentes kan man indskyde, at det netop er denne dobbelthed, som de universitære journalistuddannelser skulle skabe mulighed for.

Endelig skal det tilføjes, at Cotter (ibid.:190) tilslutter sig det forbehold, som også andre lingvister, fx Milroy og Milroy (1999), har indtaget, nemlig at forestillingen om et standardsprog inden for en gruppe snarere er et abstrakt ideal end et udtryk for den aktuelle praksis. Man vil derfor godt kunne støde på undtagelser fra normen, hvis konteksten gør det nødvendigt, fx hvis pladshensyn kræver, at man bruger en passiv i rubrikken. Det betyder naturligvis også, at det i denne artikel, der tager afsæt i lærebøgerne, primært er professionens ideelle normer, der er i fokus.

Opsummerende kan man derfor sige, at den journalistiske skrivetradition udgør en homogen og sammenhængende sprogkode med ensartede normer for, hvad der intuitivt anses for godt sprog og en god tekst. På den måde er den journalistiske skrivetradition lige så fast og normbestemt som fx den videnskabelige, som den ofte definerer sig i modsætning til. Et banalt eksempel er normerne for disposition af tekster, hvor den videnskabelige tradition som regel kræver præmisser før konklusion, mens den journalistiske nyhedstrekant kræver konklusion og pointer før præmisser.

\section{Lærebøgerne}

At der - med visse undtagelser, selvfølgelig - er tale om en tradition med ret faste normer, kan man overbevise sig om ved at læse de journalistiske lærebøger og mange how-to-do-it-bøger, som er et godt eksempel på socialiseringen ind i en bestemt sprogkultur. 
De spænder stort set over alle de fire parametre, som jeg nævnte ovenfor: De er et udtryk for, hvordan de journalistiske uddannelser (de magtfulde institutioner) favoriserer bestemte syntakser og stilistikker med konkrete handlingsanvisninger og dermed medindlærer bestemte sprognormer som særligt prestigefyldte for faget.

Ud fra disse parametre tager den pædagogiske litteratur udgangspunkt i henholdsvis negative og positive definitioner af det journalistiske sprog, nemlig de sproglige og stilistiske træk, man som journalist bør undgå, og dem, man bør bruge. Skal man kort karakterisere traditionen ud fra nogle af de mest gængse skriveråd, så består den journalistiske kode sprogligt og stilistisk af følgende konstituerende traek:

- skriv aktivt, og undgå passiv

- brug handleverber, og undgå verbalsubstantiver

- undgå klichéer og sproglige omsvøb

- undgå fagsprog

- undgå lange ord og sammenskrivninger

- undgå lange sætninger

- skriv konkret, og brug billedsprog (don't tell it, show it)

- brug narrativer, fx cases

- disponer med konklusion før præmisser

Herudover er der naturligvis en række genremæssige varianter, men de fleste lærere på vores journalistuddannelser vil næppe være uenige i disse anbefalinger, og de vil blive gentaget på redaktionerne, når de studerende oplever den journalistiske sprogkultur under praktik. Her læres sprogkulturen gennem imitation, og praksis sætter sig efterhånden som tavs viden på rygraden. For en supplerende karakteristik af journalistkoden: se fx Frandsen (1996:173ff).

Man kan derfor sammenfatte en række karakteristiske træk ved den journalistiske sprogkode:

1) Den er normativ i den forstand, at der i professionen er nogle fælles, homogene normer for, hvad der er henholdsvis godt og dårligt journalistisk sprog, og at standardiseringen ofte har karakter af dogmer. 
2) Den journalistiske kode er baseret på håndvoerksmoessige fordigheder, som primært læres gennem imitation og reflectionin-action, og som derfor sjældent problematiseres.

3) Der er derfor i lang udstrækning tale om tavs viden, som bekræftes og vedligeholdes gennem de daglige rutiner på redaktionerne.

4) Sprognormerne er ikke tilfældige, men skal forstås ud fra den institutionelle kontekst, som sproget skal fungere i.

5) Det kræver en bevidst refleksion og et metasprog at få øje på alternative muligheder, der overskrider den tavse viden.

Det vil jeg argumentere for i det følgende, hvor jeg vil bruge et enkelt af kodens karakteristiske stiltræk, nemlig verbets passivform, som illustrerende eksempel.

\section{Passiv som eksempel}

Et af de mest udskældte sproglige træk i den journalistiske skrivetradition gennem tiderne er den passive form af verbet, fx "Det besluttedes at ..." eller "Det blev besluttet at ..." i stedet for "Helle Thorning besluttede at ...". I næsten alle journalistiske lærebøger får man det råd at undgå passiv og i stedet bruge den aktive form af verbet. Brugen af passiv kobles ofte til et andet af kodens elementer, nemlig at bruge aktive verber i stedet for verbalsubstantiver, men det vil jeg lade ligge i denne forbindelse.

Et nyere eksempel er lærebogen Godt dansk (Skyum-Nielsen, 2008), som er en videreførelse og udbygning af seriehæfterne "Mediedansk", hvor man bl.a. kan læse følgende, korte karakteristik af passivformen:

\section{Pas på passiv!}

De positive råd om vores verbale kreativitet optræder kun sjældent i danske stil- og sprogbøger. Men advarslerne mod passiverne kender du sandsynligvis udmærket i forvejen.

På dansk danner vi passiv på to måder: dels som s-passiv, dels som blive-passiv. Og let spøgende kan vi samle advarslen mod begge udtryksmåder i målsætningen "Passivformer bør tilstræbes at blive undgået". 
I de følgende eksempler keder vi os nok ved s-passiverne dyrkes, ventes, lettes og indledes:

De kartofler, der dyrkes under åben himmel, ventes at være i handelen omkring grundlovsdag /TV Avisen) Ministeren vil møde fordomsfri, når forhandlingerne om, hvordan børnefamiliernes situation kan lettes, indledes.

De to s-passiver en suite virker her groteske og stærkt upersonlige: Passiverne forhindrer os i at få den ønskelige klarhed over: 'HVEM GØR HVAD?'

Der er flere typiske træk ved dette citat:

1) For det første er anbefalingen "Pas på passiv!” både kategorisk og generel, så der ikke levnes (sic!) mulighed for en nuancering af advarslen, fx ved at påpege evt. positive træk ved brugen af passiv. Men det er selvfølgelig også svært, hvis man mener, der ikke findes nogen.

2) For det andet har citatet som præmis, at læseren kender advarslerne udmærket i forvejen, og at teksten derfor skriver sig ind i en lang tradition for at fraråde passiv. Den er kort sagt en selvindlysende del af den journalistiske sprogkode.

3) For det tredje er de få begrundelser, der gives, meget typiske, nemlig at passiv gør teksten upersonlig, at den gør teksten uklar, fordi læseren ikke ved, hvem der gør hvad, og at læseren nok keder sig.

De kategoriske råd gentages i lærebøgerne, og formentlig på redaktionerne, som en indlysende sandhed, men er der overhovedet hold i disse påstande fra et sprogvidenskabeligt synspunkt? Og hvilke begrundelser og argumenter gives der for anbefalingerne? Man vil jo dels altid kunne finde eksempler på klodset sprog, både i passiv og aktiv, og man kan fx spørge sig selv, om det ikke kan være et rimeligt, journalistisk valg i det ovenstående eksempel at vinkle på og fremhæve ministeren, mens de andre aktører ved hjælp af passiven tildeles mere irrelevante roller og træder i baggrunden?

I det følgende vil jeg først give et kort, historisk rids af kritikken mod passiv, men også nogle af de (få) indvendinger, som kritikken er blevet mødt med, og jeg vil derefter antyde nogle forklaringer på, at passiven er så ugleset i journalistikken, mens den er mere udbredt og accepteret i fx den akademiske skrivetradition. 
Passiven fungerer her som en eksemplificerende case, der skal illustrere min centrale pointe, nemlig at journalisten ud fra et grammatisk og stilistisk synspunkt i princippet har en række frie, sproglige valgmuligheder, men at konteksten, dvs. institutionen (redaktionen) og dens normer, indskrænker disse valgmuligheder begrundet i traditionens selvforståelse. Eller sagt på en anden måde: Journalisten har ikke et frit, stilistisk valg, fordi brugen af passiv problematiserer den professionelle selvforståelse.

\section{Et hurtigt, historisk rids}

Det fremgår af det ovenstående lærebogscitat, at læseren forudsættes at kende advarslerne mod at bruge passiv, og det er da også en udbredt holdning, som går langt tilbage i stilhistorien. Det er heller ikke en skepsis, som er forbeholdt en dansk stil- og sprogtradition, men en skepsis, som også er udbredt i den angelsaksiske skrivetradition, som vi primært har overtaget i Danmark.

Hvor langt den kan spores tilbage, skal jeg lade være usagt i denne forbindelse, men i hvert fald advarerede William Strunk for snart hundrede år siden i klassikeren The Elements of Style (Strunk, 1918:18) under overskriften "Use the active voice" mod at bruge passiv, fordi "The active voice is usually more direct og vigorious than the passive”. Og han fortsætter:

"The habitual use of the active voice, however, makes for forcible writing. This is true not only in narrative principally concerned with action, but in writing of any kind. Many a tame sentence of description or exposition can be made lively and emphatic by substituting a transitive in the active voice for some such perfunctory expression as there is, or could be heard."

Dette råd holdes der fast ved i senere udgaver (Strunk, 1959), og man genkender rådene i fx BBC's nuværende stylebook (BBC:17f):

"At its heart, news is about people doing things. Activity is interesting. Where you can, write sentences with subjects that are 
doing things, and not subjects that are simply receiving actions upon them. Compare these two sentences:

- A meeting will be held by the company's directors next week.

- The company's directors will meet next week.

The first is an example of what grammarians call the passive voice; the second is the active voice.

Don't be put off, it's really very simple. (...) The active voice will help give your scripts some vitality and life. It can also make a weak sentence more emphatic and give it greater impact (...)."

Og med hensyn til agensstrygninger hedder det:

Governments, politicians, and officials of all kinds love the passive because individual actions are buried beneath a cloak of collective responsibility. They say mistakes were made instead of we made mistakes, and use phrases such as in the circumstances it was considered and it will be recognized that and it was felt necessary that. Used in this way, the passive takes the life out of the action and distances it from any identifiable source.

Det skal dog retfærdigvis tilføjes, at Strunk også gør visse undtagelser (op.cit.:19): "This rule does not, of course, mean that the writer should entirely discard the passive voice, which is frequently convenient and sometimes necessary."

Strunk har nemlig den pointe, at "The need of making a particular word the subject of the sentence will often (...) determine which voice is to be used." Det forbehold tager BBC også i sin News Styleguide (BBC:17) med det eksempel, at den passive "prins Edward blev trampet på af et næsehorn" er at foretrække for "et næsehorn trampede på prins Edward" - fordi den kongelige aktør er vigtigst. Det skal jeg senere vende tilbage til under den journalistiske vinkel, som netop ofte fastlægges gennem placeringen af et bestemt subjekt i starten af sætningen.

I amerikanske lærebøger finder vi de samme råd. Her kun et enkelt, nyere eksempel fra skriveguruen Roy Peter Clark fra Pointer Institute i Florida, der i sin journalistiske lærebog Skriveredskaber (Clark, 2008:31) skriver: "Scet liv i udsagnsordene. Aktive udsagnsord skaber handling, sparer ord og afslører, hvem der 
handler." Ligesom de foregående gør han dog den undtagelse, at man kan bruge passiv til at fremhæve, hvem handlingen går ud over (s. 36): "Voer passiv-aggressiv. Brug passiv til at fremhoeve, hvem handlingen går ud over."

\section{Den danske kritik}

Modstanden mod passiv overføres ukritisk fra især amerikanske lærebøger i journalistik til Danmark (Wille, 2001, s. 268), hvor vi har en tilsvarende tradition for en stort set enig kritik af brugen af passiv. Vi møder den ikke blot i de journalistiske lærebøger, men også i medieforskningen og den offentlige administration, og den er så massiv, at den efterhånden også er etableret som en almen norm for det gode skriftsprog. Hvad der er årsag og virkning, er ikke altid til at afgøre.

Når man læser de danske journalistiske loerebøger og tilsvarende how-to-do-it bøger om journalistik, er det gennemgående råd, at man skal undgå passiv/at passiv skal undgås. Eksemplerne er utallige, og jeg skal her nøjes med at nævne nogle af de mest udbredte, hvoraf de fleste er skrevet af folk, der samtidig har undervist og brugt dem på Danmarks tre journalistuddannelser. Det gælder fx Grunwald (1992), der i mange år var standardlærebog på Journalisthøjskolen i Århus og også har været brugt på RUC, Asmussen (1990), Veirup (1995), Jensen (2001), Teddy Petersen (1997, 2011), Skyum (2008), som jeg nævnte tidligere, og Thurah (2013). De må derfor siges at være repræsentative for de ideale sprognormer, som har været - og stadig er - fremherskende helt frem til i dag.

Rådene er enslydende, og et par citater kan få lov at repræsentere dem alle (Veirup, 1991):

"Skriv aktivt, og undgå passive sætninger, der hyppigt går hånd $i$ hånd med sætningsordene. (...) Problemet med passive sætninger er, at grundleddet kan udelades, ligesom det er tilfældet med verbalsubstantiverne (...) Det er en god idé at omskrive passiver til aktive sætninger, hvor det overhovedet kan lade sig gøre. På den måde kan læseren klart se, hvem der handler. Og det gør sproget mere konkret." 
Tilsvarende hedder det fx hos Teddy Petersen (2011:35):

"De (passiverne - o.a.) har samme dårlige egenskaber som verbalsubstantiverne: De lægger slør over virkeligheden. (...) Passiven fjerner (...) behovet for et ordentligt grundled, og dermed svarer vi som skribenter ikke på spørgsmålet: Hvem vil spare? Hvem formoder? Hvem henviser? Det passive udsagnsord snyder os for denne vigtige oplysning."

Og i den nyeste lærebog beregnet på de danske journalistuddannelser hedder det (Thurah, 2013):

"Passive verber kan svække såvel sætningens dynamik som dens forståelighed, fordi det bliver mindre tydeligt, hvem der gør eller siger noget (medmindre agensleddet er med som i 'bilen kørtes af chaufføren')."

Hvis man ellers tager lærebøgerne for pålydende, så har modstanden mod passiv været - og er stadig - massiv i uddannelsessystemet og dermed formentlig også på redaktionerne, selvom det sidste i denne sammenhæng må være en påstand bygget på mine egne erfaringer som sproglærer.

Men skytset mod passiven leveres også af medie- og kommunikationsforskningen med afsæt i Frands Mortensens klassiske værk Kommunikationskritisk analyse af 22-radioavisen fra 1972 (Mortensen, 1972). Her rettes kritikken mod den såkaldte agensstrygning (som senere har etableret sig som en fast betegnelse for fænomenet), hvor Mortensens afgørende pointe også er, at passiven skjuler den handlende aktør for lytteren.

Kritikken er båret af en forestilling om, at denne agensstrygning manipulerer med lytteren og virkeligheden, fordi vi ikke kan se, hvem der handler, og på den måde kommer mange fænomener og begivenheder til at fremstå som naturgivne og dermed uforanderlige. Mortensens bog er et klassisk eksempel på en ideologikritisk analyse, og vi ville måske i dag også sige et tidligt eksempel på en diskursanalyse (før det hed sådan) med fokus på usynliggørelsen af magtforholdene i samfundet. Agensstrygnin- 
ger er derfor, mener Mortensen, bevidst manipulation af læseren (Mortensen, 1972:18):

"En kommunikationskritisk analyse arbejder således ud fra en teori om, at en tekst indeholder flere meddelelser. For det første er der det umiddelbart iagttagelige, tekstens åbenlyse budskab. For det andet er der det "skjulte", tekstens tilslørede forsøg på manipulation af læseren."

Inden for den offentlige forvaltning og den sproglige rådgivning møder vi den samme kategoriske kritik med udgangspunkt i Justitsministeriets cirkulære af 1968, hvor man bl.a. kan læse: "Når det handlende led er noevnt $i$ satningen, bør aktivformen normalt foretrcekkes". Denne forsigtige, ministerielle kritik af kancellistilen fik stor normsættende virkning med den senere formand for Dansk Sprognævn, professor Erik Hansens, populære formidling i Ping og pampersprog (1971), og sammen med Statens Informations pjece - og uden omsvøb, tak (1981) dannede den - med afsæt i 60'ernes velfærdssamfund og ungdomsoprør - skole for en række lignende bøger inden for den sproglige rådgivning om, hvordan forvaltningen bør skrive til borgerne, $\mathrm{fx}$ Møller (1981) og Jensen (1998). De er alle båret af det demokratiske kommunikationsideal, som også udgør en væsentlig del af det journalistiske professionsideal.

Alle disse retninger er, malet med bred pensel, løbet sammen i en normativ, til tider dogmatisk, forståelse for, hvad der generelt - både inden for det offentlige og det private - kendetegner et alment godt skriftsprog, sådan som det fx kommer til udtryk i den meget populære Håndbog i Nudansk, som udkom i 1988, og siden er blevet optrykt i utallige oplag. Her kan man bl.a. læse i artiklen om Godt sprog (ibid.:214):

"Pas på med passiv. Passivformer gør ofte en tekst upersonlig. Man skal derfor passe særlig på med at bruge passiv. Skriv ikke: Der meddeles herved henstand med betaling af ... Skriv hellere: Skattedirektoratet giver Dem hermed henstand med Deres betaling af ..." 
Som vi har set i de ovenstående eksempler, kan begrundelserne mod at bruge passiv variere lidt i litteraturen. Mange gange advares (sic!) der mod passiv uden begrundelser, andre gange får man begrundelser, og hvis man skal sammenfatte dem, så gives (sic!) der i litteraturen hovedsageligt følgende begrundelser:

1. Teksten bliver uigennemskuelig, uforståelig og upræcis, fordi subjektet udelades, så man ikke kan se, hvem der handler.

2. Teksten bliver upersonlig.

3. Sproget bliver udynamisk og kedeligt, så læseren står af.

Begrundelserne relaterer sig altså til konteksten ud fra nogle forudsatte forestillinger om forståelighed, afsender-modtagerrelation samt en årsagssammenhæng mellem stilistik og effekt.

\section{Forsvaret for passiv}

Der er formentlig nogle nærliggende forklaringer på, at modstanden mod passiv er blevet noget af et mantra i journalistikken:

For det første er det vigtigt at forstå kritikken historisk som en reaktion imod en akademisk og administrativ skrivetradition, som netop er konstitueret ved de tidligere nævnte stilistiske træk, og som bruges af de ekspertkilder, som journalisterne skal formidle og sprogligt transformere ud fra. Begrebet 'kildeafsmitning' er et fyord i lærebøgerne, og modreaktioner har det som bekendt med at smide barnet ud med badevandet.

For det andet er det typisk, at der er tale om funktionelle skriveråd, mens den grammatiske og strukturelle beskrivelse af fænomenet er yderst sparsom. Det almindelige er, at der skelnes mellem aktiv og passiv samt de to passivbøjninger - s-passiv og blive-passiv. Det nævnes fx ikke, at blive-passiven semantisk er en form, der som regel betegner en begivenhed med en klar forestilling om en agent, mens s-formen ikke nødvendigvis har en agent, men kan henvise til forestillingen om naturlove som i fx 'Stjernerne tændes'. De såkaldte 'deponente verber', som har passiv form, men aktiv funktion (eller omvendt), fx 'Jeg længes' eller 'Døren åbner', omtales heller ikke. 
Det er der for så vidt ikke noget mærkeligt i, for der er typisk kun udvalgt den grammatiske beskrivelse, som forfatterne anser for at være nødvendig, for at rådene kan omsættes i praksis. Det kan så have netop den (utilsigtede) konsekvens, at rådene tages meget håndfast og bogstaveligt ud fra en commonsense-forståelse uden de nødvendige nuancer og alternativer, og det kan måske også forklare (noget af) deres store gennemslagskraft.

Cotter (ibid.:190) er inde på en lignende forklaring om journalisters forhold til sproget:

"Unsurprisingly, as they are not trained as linguists, in absence of descriptive linguistic knowledge, the conclusions and assessments of news practitioners are prescriptive, and embody familiar "lay" notions of language (...)."

Det kan måske forklare, at de få forsvar for passiv, man kan finde herhjemme, kommer fra lingvister.

En af dem er Heltoft (1978), der i en kort artikel har kritiseret Frands Mortensens analyser af agensstrygninger i radioavisen, især påstanden om, at de manipulerer os til at opfatte menneskelige handlinger og bevidsthedsprocesser som naturfænomener og dermed skjuler magtudøvelsen. Pointen i Heltofts artikel er, at vi som sprogbrugere udmærket er klar over, hvornår agens er et levende væsen eller et naturfænomen, men at det blot ikke kommer til udtryk i sprogets overfladestruktur.

Den mest markante kritik kommer dog fra den pragmatisk inspirerede sprogvidenskab, hvor Mogens Løj og Niels Erik Wille har forsøgt at imødegå den massive kritik og nuancere brugen af passivformen grammatisk, stilistisk og pragmatisk i en ældre artikel i NyS med den underfundige titel Kan vi undvoere passiv? eller Kan passiv undvoeres? (Løj og Wille, 1985). Selvom det er en ældre artikel, så er den stadig i denne sammenhæng det mest grundige og velargumenterede forsvar inden for dansk sprogvidenskab for brugen af passiv.

Hovedpointen i artiklen er, at kritikken af passiven har været og er alt for generel og kategorisk, og at der er meget lidt videnskabeligt belæg for kritikken. Tværtimod mener forfatterne, at passivformen har mange hensigtsmoessige funktioner - hvis man ellers ikke bedømmer den normativt, men i stedet vurderer bru- 
gen af den funktionelt ud fra konteksten og formålet med kommunikationen. Artiklen er møntet på fagtekster , især den sproglige rådgivning inden for den offentlige forvaltning, men dens pointer kan i vid udstrækning overføres til journalistikken.

Jeg vil ikke gå i dybden med argumentationen her, men blot nævne, at forfatterne med afsæt i den amerikanske lingvist Noam Chomsky og den såkaldt generative transformationsgrammatik skelner mellem beskrivelsen af passiven på to niveauer, nemlig det grammatisk-stilistiske og det pragmatiske. På det første niveau giver passiven i princippet en række frie valgmuligheder for skribenten, mens valget på det andet niveau determineres og begroenses af konteksten. Skal man sige det polemisk, så er det forskellen mellem på den ene side at være mangfoldig og kreativ og på den anden side ensrettet og konform i sine sproglige valg. Endelig har Blom (2008:37-40) i sin ph.d.-afhandling om talesprog på DR og TV2 fremført en lignende kritik af passivens funktioner i journalistikken.

Hvis jeg skal prøve kort at sammenfatte kritikken, så handler det om, at lærebøgernes beskrivelse af passiven trods forfatternes gode intentioner er for utilstrækkelig og unuanceret til at understøtte de skriveråd, man giver.

Sproget har både en overflade- og en dybdestruktur, og det bruges altid i en kontekst, og derfor kan det beskrives ud fra flere vinkler: en grammatisk, som handler om regler for opbygning og anvendelse, en semantisk, som handler om betydning, og en pragmatisk, som handler om sprogets funktion i en social kontekst.

På det strukturelle plan kan passivformen beskrives grammatisk og semantisk ud fra en overflade- og en dybdestruktur. I praktikantens rubrik Kvinde fundet død i lejlighed er kvinden på overfladeniveauet grammatisk subjekt for det passive verbum, mens agens, dvs. det væsen, der semantisk set udfører handlingen, er skjult i dybdestukturen uden at komme til udtryk. Semantikken bestemmer derfor, hvilke logiske betydningstransformationer der er mulige, fx at agens nødvendigvis må være et levende væsen, når der som her er tale om et handleverbum - modsat fx Stjernerne toendes på himlen, som er et naturfænomen, medmindre man da har bevaret sin barnetro på Vorherre. 
Til dette plan må man også henføre stilistikken, som ud fra den nære kontekst, genren, determinerer sproget. En videnskabelig afhandling vil fx favorisere brugen af passiv, mens en reportage vil gøre det modsatte. At mestre genrekonventionerne er at mestre professionens normer i praksis, eller sagt på en anden måde: Genren kan opfattes som krydsfeltet mellem den strukturelle og den funktionelle sprogbeskrivelse.

På det funktionelle plan kan passiv imidlertid beskrives ud fra en pragmatisk tilgang ud fra dens funktion i en social kontekst. Det vil sige, at man blandt de semantiske muligheder vælger nogle bestemte agenter eller udelader dem, fx afhængig af en vurdering af formålet, målgruppen, den mest relevante vinkel, i dette tilfælde offervinklen, eller slet og ret ud fra en etableret institutionel norm - sådan som vi så det i det indledende eksempel.

Et grundlæggende problem i lærebøgerne er, at omtalen af passiv primært forholder sig til en grammatisk og stilistisk beskrivelse af fænomenet, men kun sjældent inddrager den semantiske og (især) den pragmatiske. Dermed bliver brugen af passiv reduceret til et spørgsmål, som primært går på, at den ene form 'intuitivt' er at foretrække for den anden - uanset konteksten.

Pragmatisk set er der altså mange valgmuligheder, og alle niveauer må principielt tages med i overvejelserne om brugen af aktiv eller passiv. Jeg vil derfor i det følgende kort tage afsæt i lærebøgernes generelle kritikpunkter af passiven ovenfor for at vise, at de ikke nødvendigvis holder for en nærmere analyse, men er udtryk for stilistiske begrænsninger i stedet for stilistiske valgmuligheder.

\section{Eksempler på frie valg}

\section{Påstand 1: Teksten bliver uforståelig og upræcis på grund af agensstrygninger, fordi vi ikke kan se, hvem der handler.}

Den centrale pointe her er, at agensstrygning ikke nødvendigvis gør sætningen uklar eller uforståelig, men at der blot er tale om, at agenten ikke ekspliciteres som grammatisk subjekt. 
Det kan fx være, fordi læseren kender agens på forhånd, fordi det opfattes som irrelevant, eller fordi man ønsker at fremhæve et bestemt tema ved at flytte det helt frem i sætningen. Valgene afhænger derfor af, hvordan journalisten vurderer vigtigheden og relevansen af agens, og her er der flere typiske muligheder, fx:

- agens er irrelevant: Det er tilfældet i eksemplet ovenfor, hvor den myrdede kvinde er i fokus, mens det er irrelevant, hvem der fandt hende. Valg af passiv hænger altså her tæt sammen med valg af journalistisk vinkel på historien.

- agens er indlysende: Her fremgår agens af den interne kontekst, fx: "Kommunens økonomiudvalg besluttede at bevilge beløbet, og det blev endvidere vedtaget at ...." Her er man ikke i tvivl om, at agens for 'vedtaget' stadig er 'kommunens økonomiudvalg', men det ville give en meget tung og ensformig tekst, hvis man skulle blive ved med at gentage det samme grammatiske subjekt. Det samme gælder for den eksterne kontekst, dvs. når afsender og modtager har en fælles forståelsesramme. Også her kan overdreven eksplicitering af agens blive opfattet som overflødig overskudsinformation.

- agens er mangfoldige aktører: Andre gange kan agens være mange og forskellige som i det klassiske skilt med 'Cykler fjernes uden ansvar'. Her kunne det grammatiske subjekt fx være politiet, viceværten, husejeren, tyven osv., men det er ikke vigtigt for forståelsen, hvem der evt. fjerner cyklen, for pointen er udelukkende at advare om, at den bliver fjernet.

- agens er en flerhed: Det samme gælder "Det siges på Christiansborg, at forhandlingerne er gået i hårdknude", hvor det kan være svært, eller irrelevant, at udskille enkeltaktører. Her er det efterfølgende udsagn resultatet af en mangfoldighed af kilder og rygter, som journalisten har opsnappet.

- agens er almen: Nogle gange kan passiv bruges til angive en udbredt opfattelse eller offentlig mening, fx: "Det hævdes ofte i den offentlige debat at ..." Her kan passiv som oftest erstattes med 'man', så man (sic!) kan konstruere en sætning med et grammatisk subjekt og aktivt verbum, men hvem der hævder noget, bliver ikke mere klart af den grund.

- agens er ukendt: Mange gange er agens ukendt, fx: "Mand overfaldet på åben gade", som i aktiv ville hedde noget i retning af: ”En eller flere ukendte gerningsmænd overfaldt mand på 
åben gade.” Den sidste er selvfølgelig også gangbar, men igen må det bero på journalistens valg og vinkel.

- agens er upersonlig: Mange gange vil det virke nærmest komisk at bruge det grammatiske subjekt, når agens er upersonlig: "Bilist dræbt mod træ" vinder næppe meget ved at blive omskrevet til aktiv: "Træ dræber bilist" - hvis træet i det hele taget kan opfattes som agent. Det samme gælder, når naturkræfter og naturlove er på spil som i "Verdensrummet udvides". Den slags passiver er der ofte brug for i fx videnskabsjournalstikken, og ganske særlig når man bevæger sig inden for det naturvidenskabelige område.

Nogle gange kan der (i parentes bemærket) historisk ske morsomme forvandlinger: "Lufttrykket forskydes mod øst" i vejrudsigten handler ikke om naturkræfter, men om at 'Meteorologen forskyder lufttrykket ...", for meteorologen havde tidligere en 'forskyder', en slags lineal, til at flytte lufttrykket på kortet. En handling i arbejdsprocessen er altså historisk blevet forvandlet til en naturkraft.

- agens skal sløres: Og så er der naturligvis den variation, som udgør den mest dominerende kritik mod agensstrygninger, nemlig at sløre den handlende. Og det kan man jo faktisk have brug for en gang imellem som journalist, fx når man bevidst vil sløre sin kilde for at beskytte den: "Det siges, at ... Det oplyses, at ... Det hævdes, at ..."

- agens og tematisering: Endelig er det vigtigt at holde fast $\mathrm{i}$, at passiv kan bruges til at tematisere (vinkle) historien ved at flytte et bestemt led frem i sætningen, og det kan i princippet være alle led, typisk genstandsled, hensynsled og verbum. Det sidste vil fx tematisere selve handlingen eller begivenheden: "Sprængt $\mathrm{i}$ småstykker af vejsidebombe" eller "Kørt i sænk af bureaukratiet".

Der kan sikkert findes endnu flere variationer og muligheder, fx når man bruger passiv for variationens skyld, eller fordi den på grund af sin kortere form er velegnet til en lille rubrik. Eller for at løse syntaktiske problemer, fx en passiv og en præposition i stedet for en indskudt sætning (som også er ugleset i koden): "Forslaget blev fremsat af ministeren, som vil sikre sig genvalg næste 
år" i stedet for: "Ministeren, som vil sikre sig genvalg næste år, fremsatte forslaget."

Den centrale pointe her er imidlertid, at brugen af passiv i journalistik i mange tilfælde faktisk vil være hensigtsmoessig, så længe den tager højde for læserens forudsætningsniveau, og at den kan bruges, uden at teksten - som kritikken hævder - bliver uklar og uforståelig for læseren. Tværtimod kan den løse nogle stilistiske problemer, fx en unødvendig og ensformig gentagelse af tunge grundled, når det er indlysende ud fra konteksten. Det er derfor skudt langt over målet, når man generelt og kategorisk advarer mod at bruge passiv, fordi den går ud over forståelsen. Tværtimod er passiv et vigtigt element, når det $\mathrm{fx}$ gælder om at vinkle sin artikel.

\section{Påstand 2: Teksten bliver upersonlig, når man bruger passiv.}

Den anden begrundelse mod brugen af passiv er, at den gør teksten upersonlig, og det er naturligvis rigtigt i den forstand, at passiven som grammatisk form gør det muligt at udelade de parter, der er involveret i kommunikationen, fx et 'jeg' og et 'du'. Dermed får den stilistisk betydning for den relation, som fastlægges mellem afsender og modtager i teksten, fx: "Svar bedes indsendt til kommunen" i stedet for: "Jeg/vi vil bede dig/Dem om at indsende ...".

Men igen afhænger det stilistiske valg selvfølgelig af den relation, som journalisten ønsker at fastlægge i teksten, fx om han ønsker at sætte sig selv i centrum ved at bruge 'jeg' i reportagen, eller om han ønsker at inddrage modtageren med en direkte henvendelse med fx 'du'. Unge vil nok foretrække det direkte 'du', mens ældre måske vil blive irriterede over, at det nu efterhånden også har bredt sig til fx nyhederne og DMI's vejrudsigt: "Når du skal ud at køre i morgen, skal du passe på, at du ikke ..." Den direkte pseudohenvendelse opleves måske som anmassende, så man foretrækker den stilistiske mulighed, som politiet betjener sig af: "Forsigtig kørsel tilrådes ..." eller 'man' (se fx: Franch, 2013:7).

En reportage med et overforbrug af 1. person risikerer at fjerne fokus fra sagen og sætte journalisten selv i centrum, måske så meget, at det for nogle modtagere vil tendere det selvpromo- 
verende. Man behøver her bare tænke på de efterhånden gængse selviscenesættelser med journalisters standup i stormvejr: "Jeg står her på kajen i Hirtshals, og jeg er lige ved at blæse helt omkuld, for jeg ... ups!"

Her er der igen en skala af stilistiske valgmuligheder fra det personlige til det upersonlige, som ofte vil være afhængig af $\mathrm{fx}$ genre og medie, men generelt at fraråde passiv som grammatisk form, fordi teksten bliver upersonlig, vil være på forhånd at lukke af for andre og måske mere hensigtsmæssige valgmuligheder.

\section{Påstand 3: Passiv gør sproget udynamisk og kedeligt}

I lærebøgerne optræder 'udynamisk' og 'kedeligt' nærmest som synonymer, så derfor er der enten tale om en cirkelslutning, eller også må man præcisere og definere de to begreber nøjere. I lærebøgerne optræder de som oftest som årsag og virkning, således at den grammatiske passivform formodes at have den effekt, at læseren keder sig, mens det forholder sig omvendt med den aktive form. 'Dynamik' er altså en definition, som relaterer sig til selve den (narrative) fortællestruktur, mens 'kedelig' henholdsvis 'spændende' relaterer sig til modtagerens oplevelse. Disse årsagsrelationer foretages som regel helt automatisk uden yderligere begrundelser.

Det interessante er, hvor denne forestilling stammer fra, og man kan få en antydning ved at nærlæse det tidligere nævnte citat fra The Elements of Style (1918) og lægge mærke til, hvordan Strunk nærmest umærkeligt, og helt uden argumentation, overfører sproglige træk og kvaliteter fra narratologien til kategorisk at gælde alle andre tekster:

"The habitual use of the active voice, however, makes for forcible writing. This is true not only in narrative principally concerned with action, but in writing of any kind"

Det ligger uden for denne artikels rammer at gå ind i en diskussion af journalistikkens afhængighed af den narrative fremstillingsform, men i journalistikken har begrebet 'historie' i hvert fald to betydninger, der er centrale i denne sammenhæng: Det kan dels relatere sig til indholdet, dvs. emne eller tema, og dels til 
den narrative form, dvs. måden, man fortæller på. Det, der kendetegner journalistikken, er, at den formidler faktuelle emner, men ofte trækker på narrativ fremstilling bestående af aktører, der handler i et begivenhedsforløb, der udspiller sig i tid og rum - en udvikling, som i stigende grad har præget også den hjemlige journalistik, fx med begreber som 'faktion' og 'infotainment'.

Den journalistiske fremstilling trækker derfor også på forestillingen om effekter hos modtageren, som vi normalt forbinder med fiktion, dvs. historier, der med Strunks ord er "concerned with action", som i lærebøgerne vel bedst kan oversættes til begreber som fascination, identifikation og underholdning, jf. Larsen (1990), Kinch-Jensen (2001) og Hvid (2007).

Der er ingen grund til at betvivle denne forbindelse mellem valg af en bestemt fortælleform og en bestemt effekt, som er lige så gammel som retorikken og dens begreber logos, etos og patos, men der er grund til at stille spørgsmålstegn ved, om den ukritisk- som Strunk gør det - uden videre kan overføres til andre genrer, som er strukturelt betingede, fx argumenterende tekster, baggrundsartikler og analyser - og i mange tilfælde også nyheder. Nogle gange kan det endda være ønskeligt at undgå den narrative fremstilling, fordi fortællestrukturen ofte tvinger journalisten til at tænke i dramaturgiske roller og udnævne nogle aktører til helte og andre til skurke med tilhørende egenskaber og relationer, sådan som fx Gitte og Magnus Harald Haslebo ud fra en socialkonstruktivistisk indfaldsvinkel har påvist det i pressens behandling af Lars Løkkes feriesag og Helle Thornings skattesag (Haslebo, 2010). Her ville en logosappel til en "på-den-ene-sideog-den-anden-side-fremstilling” måske være mere hensigtsmæssig.

Pointen er igen, at en kategorisk og generel modstand mod passiv til fordel for en anbefaling af 'den aktive stemme' vil udelukke andre og måske mere hensigtsmæssige valg, $\mathrm{fx}$ begrundet i læserrelevans.

\section{Stilistiske valg er bundet af konteksten}

Jeg har i det ovenstående prøvet at vise, at passiv er en grammatisk form, der i mange situationer udgør et hensigtsmæssigt, 
stilistisk valg. Det kan derfor undre, at den har været og stadig er udsat for en så massiv og kategorisk kritik, at modstanden mod den nærmest er blevet et indiskutabelt mantra i den journalistiske sprogkode. Hvor kommer disse kategoriske forestillinger fra?

Svaret er næppe entydigt, men en stor del af det skal formentlig findes i den institutionelle og samfundsmæssige kontekst, som det journalistiske sprog er forankret i, og som på forhånd begrænser de frie, sproglige valg. Generelt betyder konteksten, at der i den professionelle, journalistiske selvforståelse er en række faktorer, som gør brugen af passiv problematisk, mens omvendt den aktive form passer som hånd i handske til den selvsamme selvforståelse.

Her vil jeg kun antyde nogle plausible forklaringer, hvor passiven aktualiserer og/eller problematiserer den journalistiske selvforståelse, nemlig forståelsen af koderne og genrerne, afsender-modtager-relationen, publikum og institutionens normer. Og det er ikke altid til at afgøre, om det er hønen eller ægget, der kommer først.

\section{To forskellige sprogkoder:}

Et vigtigt træk ved den journalistiske kode er, at den er blevet - og stadig bliver - opfattet i forhold til sin modsatning, nemlig det administrative, politiske og videnskabelige sprog, som typisk er (ekspert)kildernes sprog. Journalistik opfattes i denne selvforståelse som formidling, dvs. transformation og forenkling fra et svært tilgængeligt til et let tilgængeligt sprog, som ligger tæt på hverdagssproget (Frandsen, 1996).

Kodernes stilistiske træk er såvel i sprogvidenskaben som i lærebøgerne systematiseret i to forskellige slags sprog, der ofte (fejlagtigt) opfattes som hinandens modsætninger, hvoraf videnssprog og erfaringssprog er en af de betegnelser, der ofte benyttes (Larsen, 1987). Det gælder derfor logisk nok - som der ofte står i lærebøgerne - om at undgå kildeafsmitning fra netop de stilistiske træk, som kendetegner videnssproget, og det er blandt andet typisk passiv, som i ekspertkoden ofte bruges som det stilistiske signal for upersonlighed og objektivitet. 


\section{Genren:}

I det ovennævnte citat fra Strunk sker der som nævnt en glidning mellem forskellige genrer, hvor normen om 'the active voice' helt umærkeligt udvides til ikke blot at gælde narrative genrer, men alle genrer generelt, og det er en udvikling, der forstærkes i journalistikken.

Tidligere tiders rent informative genrer, som fx kendetegnede omnibuspressen, har fået stadig større konkurrence fra fortællende genrer, og begreber som identifikation, fascination og underholdningsværdi er kommet mere og mere i fokus i journalistikken. Begrebet 'historie' handler ikke kun om emne og indhold, men også i stigende grad om selve den narrative form 'at fortælle en historie', som modtageren finder spændende.

Narrative genrer handler ikke om fx samfundsmæssige strukturer, men om aktører, der handler i tid og rum, og det kræver fremstillingsmæssigt den aktive form med agens som subjekt og aktive handleverber. I journalistik hedder det som regel, at teksten skal være 'dynamisk' i modsætning til 'statisk'. Det handler med andre ord om dét, man populært kunne kalde "indpakningen". Information anses ikke for at være tilstrækkelig i sig selv, men må tilsættes noget mere, som Harms Larsen meget rammende har døbt "journalistisk merværdi".

Jeg vil godt tilføje, at jeg som udgangspunkt ikke er uenig, men det betyder dog ikke nødvendigvis, at de informative og argumenterende genrer som fx nyheder, analyser, baggrund og kommentarer kræver det samme.

\section{Publikum:}

Forestillinger om genren er tæt forbundet med - og et resultat af - journalistikkens forestillinger om publikum, dvs. læsere, lyttere og seere. Jeg har andetsteds (Jensen, 2001:226ff) skitseret otte typiske forestillinger om publikum, som - oftest ubevidst for os selv - styrer vores kommunikation i form af en modellæser (a la tabloidpressens Maren i Kæret), men her vil jeg kun nævne nogle fremtrædende, som har været på spil i den journalistiske selvforståelse. Det er vigtigt at understrege, at de alle stadig er 
i spil i forskellige kombinationer, selvom de tilhører forskellige arkæologiske lag i journalistikkens historie.

Meningspressens - og senere omnibuspressens - forestillinger om publikum var den oplyste og dannede loeser, sådan som fx Habermas skildrer det i idealet om den borgerlige offentlighed (Habermas, 1975), og som stadig lever i forestillingen om den læser, der skal sikres den fornødne viden til at varetage sine demokratiske forpligtelser og træffe rationelle og begrundede valg. Begrundelsen for public service relaterer sig til denne forestilling, og den er stadig et vigtigt, arkæologisk lag i den journalistiske selvforståelse. Modsætningen er tabloidpressens uoplyste og udannede modellæser 'Maren i Kæret', som stadig er i live, derude hvor kragerne vender.

Men de to har fået konkurrence fra tre andre forestillinger, som er blevet mere og mere fremtrædende gennem de sidste par årtier, bl.a. sammen med udviklingen af de elektroniske medier og nye platforme, nemlig den adspredte, den genstridige og kunden.

Den adspredte og den genstridige har én ting til fælles, nemlig at de af journalisten ofte opleves som vanskelige at komme i kontakt med, fx fordi de har andre ting at tage sig til, fx surfer på nettet eller er umotiverede. Målgruppen opfattes kort sagt som en modstand, som derfor logisk nok må overvindes med action, fascination og underholdning. Man forudsætter grundlæggende ikke en læser, der er interesseret eller motiveret på forhånd og gerne vil gøre et stykke arbejde for at forstå problemstillingen stik imod det demokratiske ideal, som ellers udgør en vigtig del af den journalistiske selvforståelse, jf. kritikken i Koch (2011) af de "fordummende uskikke" i den offentlige debat. Det ligger efterhånden dybt i den journalistiske selvforståelse, at man under ingen omstændigheder må kede læseren, det gentages ofte i lærebøgerne, og det gør passiven uegnet, fordi den i den journalistiske selvforståelse skaber udynamiske og kedelige tekster, som jeg allerede har været inde på.

Forestillingen om Kunden har også fået en mere og mere dominerende rolle som modellæser sideløbende med servicejournalistikken, som kræver en tæt og personlig relation. Samtidig har de nyere medier og platforme, fx nettet og sms'en, skabt mulighed for en større dialog mellem journalister og kunder, som lægger 
op til den personlige og uformelle relation (sms din historie til os osv.). Også her opfattes passivformen som uegnet og blokerende for kontakten.

Endelig skal man heller ikke glemme, at relationen mellem medieinstitutionen og dens publikum bygger på frivillighed, dvs. at publikum til enhver tid kan sige fra og læse en anden avis, surfe et andet sted hen eller skifte over på en anden kanal. Kravet om at være udfarende og pågående er derfor formentlig en tendens, der kun vil forstærkes i den stigende konkurrence medierne imellem.

\section{Afsendernormer:}

Medieinstitutionen har sine egne normer og praksisbetingelser, herunder at man har rollen som den kritiske, fjerde statsmagt, hvor afslørende journalistisk i stigende grad opfattes som et ideal, dvs. at fx politiske aktører skal afsløres, hvis de ikke lever op til deres ansvar, sådan som begrundelserne ofte lyder, når Cavling-prisen uddeles (Schultz, 2006). Som Ekstra Bladet engang har formuleret det, vil der altid være en person, som kan drages til ansvar - og det i sig selv gør logisk nok agensstrygning suspekt. Samtidig har der været en stigende tendens til at fokusere på processer frem for strukturer, og når man skildrer virkeligheden på aktørplan, så kræver dramaturgien, at der er skurke, helte og ofre - og de kræver alle en agent som subjekt i fremstillingen.

Sammenfattende kan man altså pege på en række generelle tendenser i journalistikken, som sandsynligvis forstærkes og determinerer brugen af aktiv i stedet for passiv, og der kan formentlig nævnes endnu flere.

\section{To referencerammer}

Der er i princippet to overordnede referencerammer for bedømmelse af sprog, nemlig den normative og den funktionelle. 
I den normative tilgang bedømmer vi sproget ud fra vores egne sprognormer, hvad enten de er individuelle eller institutionelle, og det sidste gælder fx normative forestillinger om det gode sprog i videnskab, offentlig sprogbrug (kancellistil) og journalistik. Når man vurderer normativt, er man sjældent i tvivl om, hvad der er godt og dårligt sprog, for det ligger som regel så meget på rygmarven hos professionens udøvere, at det bedømmes ud fra intuition, som jeg tidligere var inde på. Det er ikke nødvendigvis dårligt i sig selv, for det er en nødvendig del af journalistens faglige kompetence. Det er først et problem i det øjeblik, at normerne bliver så dogmatiske, at det bliver svært at reflektere bevidst over brugen af sproget og begrunde sine valg - endsige finde alternativer, der ligger uden for de vedtagne normer.

Den anden tilgang til sproget er den funktionelle, og det vil sige, at sprogbrugen bedømmes og begrundes i forhold til nogle eksplicit givne referencerammer, som fx kan være formål, målgruppe eller anden form for kontekst. Det gode sprog er det sprog, der opfylder afsenderens hensigt, og derfor bliver det også muligt at argumentere ud fra nogle eksplicitte kriterier, som ligger uden for personerne selv i form af en fælles referenceramme.

Modsat journalister ligger det i kommunikationsfolks uddannelse at tænke funktionelt over sproget i form af bevidst, strategisk planlcegning af fx kampagner ud fra formål, effekt og målgrupper (fx Jakobsen 1997, Sepstrup 2006), og kommunikationsfolk tænker derfor også i specifikke målgrupper i modsætning til journalister, der ofte abstrakt og diffust tænker i publikum, læsere, lyttere og seere. Fremkomsten af segmentpressen (Schultz 2007) har dog efterhånden fremmet tendensen i medierne til at tænke i målgrupper ud over "Maren i Kæret", selvom det stadig strider mod journalisters normative og intuitive tilgang til sproget, der tilsiger, "hvordan man plejer at gøre".

I journalistikken tenderer det normative og det funktionelle kriterium mod at flyde sammen, så det bliver sværere at holde dem ude fra hinanden. Hvis det funktionelle kriterium er næsetælling og klik på nettet, så afstikker det også normerne for den gode historie og det gode sprog - og vice versa. Det er en cirkelslutning, der fungerer selvbekræftende, så længe kriterierne ikke drages i tvivl. Når praktikanten drager normerne i tvivl, får 
han ofte at vide, at "sådan vil læserne have det" - også selvom læserne reelt ikke har fået tilbudt nogen alternativer.

Man skal bestemt ikke kimse ad den sproglige funktionalitet, der bygger på erfaring, som tilfældet er i journalistikken, men det er et problem, hvis normerne fremstår som sandheder, der ikke kan drages i tvivl eller nuanceres - eller i det mindste kan forsvares med en argumentation, der ligger ud over de professionelle mavefornemmelser. Det gælder ikke kun passivformen, som jeg har brugt som eksempel her, men også de andre normer, som jeg nævnte indledningsvis:

Brugen af verbalsubstantiver kan fx nuanceres på samme måde som passiven, fagsprog er selvfølgelig velegnet på fagbladet, og klichéer - som i journalistikken ligefrem lægges for had (Meisner, 2004) - er i mange tilfælde præcise og relevante for vores forståelse af teksten. Den mekaniske lix-måling (Björnsson, 1971), som bygger på ren statistik uden årsagsforklaring, bruges stadig $\mathrm{i}$ flere lærebøger, og forestillingen bag den tilskynder til et ophakket og usammenhængende staccatosprog, bl.a. tabloidpressens såkaldte "gule sprog", selvom lange sætninger godt kan læses og forstås, så længe de er skruet logisk sammen (Rask, 1993). Man kan også diskutere, om det altid er hensigtsmæssigt at placere pointen i nyhedstrekantens allerførste linje, eller om man bør give læseren noget baggrund og nogle forudsætninger først.

Jeg vil ikke påstå, at disse normer nødvendigvis er uhensigtsmæssige, men der er mange undtagelser fra de dogmatiske regler, sådan som jeg har prøvet at vise.

\section{Et pædagogisk dilemma}

Pædagogisk set udgør de to kriterier for godt sprog et dilemma, når kommende journalister skal socialiseres ind i faget og professionen - hvad enten det sker gennem fagets lærebøger og undervisning eller i praktik. Dilemmaet består i, at de studerende på én og samme gang skal tilegne sig fagets eksisterende normer, samtidig med at de skal reflektere kritisk over dem og måske gøre noget alternativt.

Mange års erfaringer som sproglærer på journalistuddannelsen på Roskilde Universitet har lært mig, at de studerende efter- 
spørger faste regler, dvs. at de vil have normative regler for, hvad der er godt, journalistisk sprog: Må vi bruge passiv eller ej? Svar udbedes. Og det er selvsagt et problem, hvis man - som jeg - står for et funktionelt sprogsyn, dvs. at hensigtsmæssige, sproglige og stilistiske valg afhænger af formålet og den konkrete kontekst, og det bliver et endnu større problem, hvis lærebøgerne dogmatisk understøtter de normative regler. Så bliver det valne svar ofte: Tjah, det kommer jo an på ... Og det er svært for de studerende at bruge til noget, føler de.

Det er problematisk, fordi man risikerer en utilsigtet medindloering:

1) For det første kommer man til at fokusere på isolerede, grammatiske og stilistiske træk i stedet for på teksten som helhed. En af årsagerne til skriverådenes gennemslagskraft og holdbarhed er formentlig netop, at de er lette at huske og håndtere for de studerende.

2) For det andet fokuserer man på læserforståelse som et stilproblem (den rette indpakning) i stedet for de mange andre og komplicerede faktorer, $\mathrm{fx}$ indhold, relevans og kontekst, der er langt vigtigere for læserens forståelse.

3) For det tredje kommer man let til at udelukke andre alternativer.

4) For det fjerde skaber faste normer konforme tekster, der ligner hinanden, så journalistens autonomi forsvinder. Det er fx i dag svært i nyhederne at skelne den ene journalist fra den anden - det er mainstream og som regel ret kedsommeligt, stik mod intentionerne i selvforståelsen.

Underviseren sættes derfor hele tiden i et dilemma, som består i at undervise i traditionens herskende normer for godt sprog, så de studerende kan gebærde sig i branchen - samtidig med at man skal problematisere disse normer og lade dem opdage andre muligheder. Det er et dilemma, som er blevet forstærket af de to nye universitære journalistuddannelser - hvis man da ellers skal efterkomme det ønske om "nye måder at drive journalistik på”, som i sin tid var den politiske begrundelse for uddannelserne. Her forstærkes dilemmaet, fordi de to traditioner - den journalistiske og den akademiske - mødes: På den ene side den håndværksmæssige mesterlære, som altid har været journalistik- 
kens særkende, og på den anden side den analytiske og kritiske refleksion, som altid har været det akademiske særkende.

Min egen pædagogiske erfaring siger mig, at det er svært at gøre begge dele samtidig. Man må først lære normerne, før man kan bryde dem, fordi man ikke kan være alternativ ud i den blå luft uden at have noget at være alternativ i forhold til. Eller sagt med maleren Renoirs ord: "Lær først håndværket, det vil ikke forhindre dig i at blive genial". Men dermed risikerer man selvfølgelig også, at normerne når at sætte sig så meget på rygmarven, at de ikke længere kan problematiseres.

Og så blev det sidste ord meget passende en passiv.

\section{REFERENCER}

Asmussen, Kaj (1990): En god historie. Om at forvandle en stak oplysninger til en journalistisk artikel. Forlaget Grafisk Litteratur.

(The) BBC News style guide. www2.media.uoa.gr/lectures/linguistic_ archives/academic_papers0506/notes/stylesheets_3.pdf

Bell, Allen (1991): The Language of News Media. Blackwell.

Björnsson, C.H. (1991): Laesbarhed. Gad, København.

Blom, Jonas Nygaard (2008): Mediesyntaks - Om saetningskompleksitet og talesprog i DR og TV2. Institut for Sprog og Kommunikation, Center for Journalistik.

Bønløkke, Helle (2009): Smid klichésproget ud - og få plads til dit eget. Forlaget Ajour.

Clark, Roy Peter (2008): Skriveredskaber. 47 uundvcerlige råd til skribenten. Forlaget Ajour.

Comboy, Martin (2007): The Language of the News. Routledge, London and New York.

Cotter, Colleen (2010): News Talk. Investigating the Language of Journalism. Cambridge, University Press.

Franch, Rikke: Gør 'du' automatisk en tekst personlig? I: Mål og Mæle, nr. 4, 2013.

Frandsen, Finn (red.) (1996): Medierne og sproget. Aalborg Universitetsforlag.

Grepstad, Ottar (1997): Det littercere skattkammer. Sakprosaens teori og retorikk. Det Norske Samlaget.

Grunwald, Ebbe m.fl. (1992): Journalistens sprog. Forlaget Ajour.

Habermas, Jürgen (1975): Borgerlig offentlighet. Fremad. 
Hansen, Erik (1971, 2. udgave1996): Ping og pampersprog. Hans Reitzel. Haslebo, Gitte (red.) og Haslebo, Magnus Harald (red.) (2010): Nye veje for journalistik - når sprog skaber virkeligheder. Dansk Psykologisk Forlag.

Heltoft, Lars (1978): 'Lingvistik i pragmatikken. Den grammatiske semantik og 22-radioavisen'. I: Pragmatik. NyS nr. 9, Akademisk Forlag.

Hvid, Mikkel (2007): Fascinerende fortoelling. Update.

Jacobsen, Henrik Galberg og Jørgensen, Peter Stray (2005): Håndbog $i$ Nudansk. Politikens Forlag.

Jacobsen, Jan Krag (2011): 29 spørgsmål-en moderne retorik til planloegning af kommunikation. Roskilde Universitetsforlag.

Jensen, Leif Becker (1994): Ud af elfenbenstårnet. Roskilde Universitetsforlag.

Jensen, Leif Becker (1998): Kancellistil eller Anders And-sprog? Roskilde Universitetsforlag.

Jensen, Leif Becker (2001): Den sproglige dåseåbner - om at formidle faglig viden forståeligt. Roskilde Universitetsforlag.

Jensen, Ulf Joel m.fl. (2001): skriv godt.dk. Sådan skriver du gode tekster til Internettet. Frydenlund.

Jørgensen, John Chr. (2007): Journalistik med stil. Fra klassiske nyheder til fortcelling. Ajour.

Kinch-Jensen, Anders (2001): Forankring fryder. Journalistisk fortcelleteknik. DR-Multimedie \& Ajour.

Koch, Christian (2011): De svarer ikke. Fordummende uskikke i den politiske debat. Gyldendal.

Larsen, Peter Harms (1987): Skriv sundere - en kritisk brugsbog for sygeplejersker. Teknisk Forlag.

Larsen, Peter Harms (1990): Faktion - som udtryksmiddel. Forlaget Amanda.

Løj, Mogens og Wille, Niels Erik (1985): Kan vi undvoere passiv? eller: Kan passiv undvoeres? En undersøgelse af passivformernes grammatik, stilistisk og pragmatisk. I: 'Pragmatik', NyS 15, Akademisk Forlag.

Meisner, Ole (004): Haderen. Mediedansk, Syddansk Universitetsforlag.

Milroy, James and Lesley Milroy (1999): Authority in Language: Investigating Language Prescription and Standardisation. Routledge, London and New York.

Mortensen, Frands (1972): Kommunikationskritisk analyse af 22-radioavisen.GMT. 
Møller, Bent (1981): - og uden omsvøb, tak! Eller: Hvordan man ved hjoelp af lidt sund fornuft kan forbedre sine sprogvaner, når man skriver til sine medborgere. Statens Informationstjeneste.

Petersen, Teddy (1997): Skriv let-og ej med noesen i sky. Frydenlund.

Petersen, Teddy (2011): Skriv så det foenger. Frydenlund.

Rask, Kirsten (1993): Det gule sprog. Grafisk Litteratur.

Reah, Danuta (1998): The Language of Newspapers. Routledge.

Schön, Donald A. (1981): Den reflekterende praktiker - hvordan professionelle toenker når de arbejder. Klim.

Schultz, Ida (2006): Bag nyhederne - voerdier, idealer og praksis. Samfundslitteratur.

Schultz, Ida (2007): "Fra Partipresse over Omnibuspresse til Segmentpresse". I: Journalistik og presse i forandring, Journalistica, nr. 5.

Sepstrup, Preben (2006): Tilretteloggelse af information - kommunikations- og kampagneplanloegning. Academica.

Skyum-Nielsen, Peder (2008): Godt dansk. DR og Syddansk Universitetsforlag.

Strunk Jr., William (1918): The Elements of Style. New York.

Thurah, Thomas (red.) (2013): Sproget i de elektroniske medier. Hans Reitzel.

Veirup, Hans (1995): Klart og enkelt - Kort og godt. Sproglige råd til den fagmand, der skriver til gud og hvermand. Systime.

Wille, Niels Erik (2001): ”Det gode sprog. Nogle tanker om det forskningsmæssige grundlag for sproglig rådgivning i faglig formidling”. I: Lars Heltoft \& Carol Henriksen (red.): Den analytiske gejst, Roskilde Universitetsforlag. 